\title{
The Urban Zemiology of Carnival Row: Allegory, Racism and Revanchism
}

\author{
Rafe McGregor $^{1}$ (D)
}

Accepted: 17 December 2020 / Published online: 16 February 2021

(c) The Author(s) 2021

\begin{abstract}
This article makes the case for the zemiological value of Fredric Jameson's (2019) model of fourfold allegory. Zemiological value is the value in reducing harm and it is realized by means of etiology, i.e., explaining the causes of harm. I make the case using a single, detailed example, but the argument is generalizable by virtue of the relationship between fourfold allegory and contemporary social life. I begin by delineating Jameson's model of allegory as a thick narrative with four distinct levels of meaning: literal, symbolic, existential and anthropic. I explain each of these levels with reference to Carnival Row (2019)_ an urban fantasy television series that explores racism, alienation and decivilization. I conclude by demonstrating how the allegory reveals a particular combination of causes that contribute to the replacement of a cosmopolitan ideal with a revanchist reality, articulated by Gareth Millington (2011) in his theory of the racialized global metropolis.
\end{abstract}

\section{Introduction}

This article is about Prime Video's Carnival Row (2019), Fredric Jameson's (2019: 19) model of "fourfold allegory," and zemiology. Zemiology, the study of harm, is usually conceived of as a sub-discipline of criminology, but is more accurately described in critical terms-as seeking to reconfigure traditional, mainstream or conventional criminological inquiry to focus on the concept of harm rather than crime (Boukli and Kotzé 2018; Hillyard and Tombs 2004; Pemberton 2016). In my mind, zemiology is more significant than criminology, aiming to reduce harm regardless of whether that harm has been criminalized or not. In this article, I argue that Jameson's unique model has zemiological value because it is a tool for realizing the potential of complex allegories to explain the causes of harm in contemporary social life. Even more specifically, I use Carnival Row (2019), an urban fantasy television series, as a case study to explain the combination of causes that contribute to the replacement of what Gareth Millington (2011) calls a cosmopolitan ideal with a revanchist reality - a trend characteristic of global metropolises in the twenty-first century.

Rafe McGregor

mcgregor@edgehill.ac.uk

1 Department of Law and Criminology, Edge Hill University, St Helens Road, Ormskirk L39 4QP, UK 
As such, my zemiological inquiry is consistent with critical criminology in providing an alternative to both the accepted aim and the approved methods of mainstream criminology.

My zemiological interest in Carnival Row is in the series as a fictional fourfold allegory. The criminological interest in fiction has been limited to date, emerging in discrete theoretical pockets - from cultural criminology (Brown 2004; Rafter 2007; Ferrell et al. 2015), to critically orientated realism (Ruggiero 2003; Frauley 2010; McGregor 2020), to narrative criminology (Brisman 2017, 2019; McGregor 2018; Page and Goodman 2020), to ultra-realism (Hayward and Hall 2021; Raymen 2018; Wakeman 2018). The most sustained engagement with fiction has been by cultural criminology, which-with several notable exceptions (Cavender and Jurik 2012; Rafter 2006; Wood 2019) — has, for the most part, been concerned with the way in which fiction misrepresents reality. Typically, cultural criminologists assume or argue that the knowledge provided by fiction is restricted to knowledge of the production and reception of representations, rather than knowledge of the reality represented by fiction. Consequently, my inquiry can be considered as emerging from the narrative criminological framework. My method involves drawing on research in both philosophical aesthetics (McGregor 2016, 2018) and cinematic urbanism (Highmore 2005; Millington 2016), with the former emphasizing the relationship between representation and reality and the latter the way in which the city has material and symbolic reality. I first watched Carnival Row in September 2019, a few weeks after its release. I watched it twice more over the next six months, taking notes on its relevance to Jameson's (2019) model and Millington's (2011) theory, and I revisited specific sequences, scenes and episodes as necessary. The focus of this article is Jameson's model of fourfold allegory and it is to that model that I turn next.

\section{Allegory}

Jameson (2019) is highly critical of the traditional model of allegory on the basis that it divides a narrative into two distinct lines with separate, hierarchical meanings: the literal and the symbolic. Using examples such as Dante Alighieri's Divine Comedy (1472), Edmund Spenser's The Faerie Queene (1590), William Shakespeare's Hamlet (1603), Johann Wolfgang von Goethe's Faust: The Second Part of the Tragedy (1832), Karl Marx's A Contribution to the Critique of Political Economy (1859), and David Mitchell's Cloud Atlas (2004), Jameson (2019: 10) argues that genuine allegory does not impose meaning on a representation, but "functions to reveal its structure of multiple meanings." These meanings operate at four levels, Jameson (2019) contends: literal, symbolic, existential and anthropic. The "literal level" is simply "the thing demanding analysis" - the represented sequence of events in the narrative, whether they are real, imagined or some combination of the two (Jameson 2019: xvi). The "symbolic level" is concerned with the hidden or secret meaning of the represented sequence of events and the extrapolation of its meaning requires the practice of interpretation. The "existential level" is concerned with the "construction of subjectivity" and can be considered as the ethical meaning of the narrative, understood in terms of the individual (Jameson 2019: xvi). The "anthropic level" is concerned with the "collective and political narrative [that is] always latent in our conceptions of our own personal destinies" and can be considered as the political meaning of the narrative, understood in terms of the species (Jameson 2019: xvii). Jameson summarizes 
the levels at which meaning functions as: textual object, interpretive code, individual desire and collective ideology.

The significance of Jameson's (2019: 276) conception of allegory is not merely that he identifies four rather than two levels of meaning, but that an allegorical narrative is a "thick narrative." Narrative thickness refers to the integration or intersection of different axes, elements or levels in (a) representation, and in Jameson's fourfold narrative, there is a multiplicity of intersections of levels of meaning (see McGregor 2016; Williams 1985). Jameson (2019: 234) explains the implications of this this thickness: "The levels are not a collection of complete narratives superimposed upon one another. Rather they come at reality in an utterly different way, by a jarring and sometimes dissonant differentiation of their various dimensions." His theory of allegory as fourfold and thick underpins a method of interpretation in which the intersection of levels of meaning exceeds the representational capacity of narrative by activating an event in the reading (or viewing) process. The "narrative event," then, is formal (structural) rather than substantive (representational) as the allegory reveals the complexity of its architecture of multiple meanings (Jameson 2019: 263). Jameson (2019: 117, 308, 347) maintains that the narrative event is particularly useful for shedding light on the complexity of "our own moment of late capitalism"- "late capitalist globalization" and "modern social life"-by virtue of the way in which the interrelationship among the allegorical levels reveals otherwise imperceptible connections among the dimensions of late modern life. The relationship between the word (or image) and world is that the fourfold allegory provides an "allegorical staging" of the complexity of social life by means of the narrative event (Jameson 2019: 117). In other words, allegorical narratives hold up both a mirror and a microscope to everyday life and can thereby illuminate causal relations that might otherwise remain imperceptible.

With the exception of Marx's (1859) A Contribution to the Critique of Political Economy, all of the examples through which Jameson establishes his theory (and my own in this article) are fictional, which might cause many social scientists to be skeptical about employing his allegorical model in zemiological research. The main concern with employing fictional sources is the contemporary association of fiction with one or more of falsehood, imagination or invention. Consider the following sentence in Peter Ackroyd's (2000: 678) urban history, London: A Biography: "The fact that the killer was never captured seemed only to confirm the impression that the bloodshed was created by the foul streets themselves; that the East End was the true Ripper." The referents in the sentence are in no doubt: "the killer" and "Ripper" refer to the undetected serial killer commonly known as "Jack the Ripper" and "East End" to the part of London east of the City of London and north of the River Thames that includes Whitechapel. The worry, then, might be that when I watch Carnival Row (2019), the homicidal hate criminal stalking "faeries" and the city in which he commits his assaults," have no referents because both the character and the setting are fictional. Where Ackroyd's history informs one about (the real) London, Prime Video's series cannot inform us about a historical or contemporary city because the city in which it is set is invented.

The contemporary view of fiction as having little or no relation to reality because of its falsity, imaginativeness, or invention is a recent development, however, as prior to the twentieth century, representational art, in general, and poetry, in particular (exemplifying all of literary art, including fiction), were regarded as communicating more rather than less truth than other types of representations. Both the Romantic (1800-1850, for example, William Wordsworth) and Classical (800-200 BCE, for example, Plato) critical traditions accepted that poetry, literature and fiction afforded "penetration to a universal sphere of truth" (Williams 1958: 60) and that their mimesis was imitation of permanent, rather than 
temporary, reality. The idea of a permanent reality to which poetry and fiction can provide access extends back over two millennia to Aristotle's famous observation on the superiority of poetry over history: history refers to what has transpired (particulars) and poetry to the kinds of thing that can occur (universals) (McGregor 2016). Fictional characters, settings and actions refer to types of people, places and events that have happened, are happening and could happen. This is the one of the meanings of the various contemporary conceptions of the idea of truth in or of fiction (Frauley 2010; Vidmar Jovanović 2019). In urban studies, cinematic fictions (including both film and television) are recognized as a source of data, as communicating social facts about a/the city. Urban reality is constituted by a combination of the actual, empirical and material, on the one hand, and the symbolic, virtual and mythical, on the other hand (AlSayyad 2006; Penz abd Lu 2011). Cinematic urbanism is concerned primarily with depictions of real cities, but this does not preclude representations of fictional cities communicating social facts. Allegorical fictions have the potential to provide knowledge of causal relations about contemporary social life because of the referential relation between fiction and reality, which links the mythic with the material. Following Jameson, I discuss each of the four levels of meaning in turn.

\section{Literal}

Carnival Row (2019) is an urban fantasy television series that has a complex narrative architecture employing major plotlines from at least three distinct genres of fiction. My zemiological interest is in the first season, which was released in August 2019, and comprises eight episodes, each of which runs from fifty to sixty-seven minutes. (At the time of writing, a second season is in production.) The season opens as a postcolonial epic, focused on protagonist Vignette Stonemoss (played by Cara Delevingne), a faerie who flees from her native land of Tirnanoc (from the Gaelic Tír na nóg) to seek asylum in the Republic of the Burgue. While the ship on which she is traveling is sinking, a murder mystery begins in the Burgue, introducing a second protagonist, Rycroft Philostrate (played by Orlando Bloom), a police inspector. The postcolonial epic and murder mystery are linked by a paranormal romance between Vignette and Philo (the name Philostrate uses), which is represented as an interspecies romance until it is revealed that Philo himself is an interspecies hybrid, with a human father and faerie mother. The three major plotlines are further intervolved by the addition of by two minor plotlines, one political and one social, each concerned with an elite Burgue family, the Breakspears and the Spurnroses, respectively. Absalom Breakspear (played by Jared Harris) is Chancellor of the Republic, and siblings Ezra and Imogen Spurnrose (played by Andrew Gower and Tamzin Merchant) are the owners of Vignette's indenture. The minor and major plotlines are linked by means of the Burgue itself and the series takes its title from a street in the Burgue that is the center of what has become a Faerie inner city, populated by faeries, fauns, centaurs, trolls, kobolds and other refugees from Tirnanoc.

The meaning with which the literal level is concerned is the textual object-the represented sequence of events in the narrative. In Carnival Row, the actual plot-the temporal movement from the inaugural to the inevitable that constitutes the cognitive, emotional and evaluative significance of the narrative-is revealed only in the final episode (Jameson 2015; McGregor 2018). Sophie Longerbane (played by Caroline Ford), the daughter of the Leader of the Opposition in parliament, initiates her play for control of the Burgue by blackmailing the Chancellor's wife, Piety Breakspear (played by Indira Varma), sending her a faked letter from a famous Fae singer claiming that she had a child with Breakspear. Like Sophie, Piety 
is preoccupied with establishing a ruling dynasty and determined to realize the Haruspex's (witch) prophecy of Breakspear greatness. As a result, she has kept the true paternity of her son, Jonah (played by Arty Froushan), the product of an affair with Sophie's father, Ritter (played by Ronan Vibet), secret. When Piety finds out about Breakspear's illegitimate child, she fears that the prophecy applies to him (or her) rather than Jonah and sets a twofold plan in motion. First, she seeks the Haruspex's (Aoife Tsigani, played by Alice Krige) help in creating a Darkasher, a supernatural servant, which she will use to discover the identity of Breakspear's offspring. Second, she has Jonah kidnapped, frames Longerbane for the crime, and murders him while he is being subjected to enhanced interrogation. Sophie follows Burgue custom by taking her father's seat in parliament, makes a bid for popularity by adopting an extreme antiFae position and seduces Jonah, despite suspecting that he is her half-brother. Her machinations come to full fruition when a faun insurgent stabs Breakspear and Jonah is appointed Acting Chancellor. The season ends with Jonah using his father's death to declare the Burgue "a city under siege"-interning all the Fae in Carnival Row under emergency legislation.

The movement from the beginning of the season, where the postcolonial epic and murder mystery plotlines vie for significance, to the recognition that Piety is manipulating events, to the inevitable condition in which Piety, herself, is being manipulated by Sophie, provides a rich exploration of at least two zemiological themes. I use "zemiological" instead of "criminological" to indicate that these themes are concerned with phenomena that are harmful but have not been criminalized.

The first is the vulnerability of all forms of government, including democracy, to extra-parliamentary influence. In Carnival Row, the nepotism that allows the child to take the place of the parent in parliament enables Sophie's plan, but the point is relevant to our own world when one considers the power wielded by individual billionaires and global corporations and the influence they are able to bear on political decision-making. Carnival Row thus illuminates the characteristics of the powers behind the façade of democratic government and draws attention to the vulnerability of the system to determined and unprincipled individuals-Sophie and Piety in the fiction, both of whom are preoccupied with securing their influence beyond their own lifespans.

The second theme is the prevalence and danger of speciesism. Speciesism is the belief that human animals possess a superior moral status to nonhuman animals as a consequence of their species, i.e., that human beings matter more because they are assumed to be more intelligent, have a greater capacity for suffering, or demonstrate virtues of character (Beirne 2018; Singer 1993; Sollund 2019). Most human beings are speciesist courtesy of the combination of views about nonhuman animals purported inferiority, beliefs about nature being created for human exploitation, and a lack of recognition of the complexity of nonhuman animal minds. In Carnival Row, the harm of speciesism is made more obvious by the existence of a species or genus, called the Fae, many of whom are very similar to humans in appearance and identical in emotion, intelligence and virtue. Despite the obvious similarities and the equally obvious claims for equal moral status, many citizens of the Burgue believe that they are morally superior to the Fae because they (the Burgue) are human. This fear of the other is exploited by politicians. Sophie, for example, has no strong feelings about the Fae either way, but adopts an exaggerated version of her father's speciesism to begin a populist movement. 


\section{Symbolic}

Carnival Row is explicitly allegorical at the symbolic level. Filming began in 2017, two years after the peak of the migrant crisis in Europe and a year after the Brexit referendum in the United Kingdom (UK) and Donald Trump's successful presidential campaign in the United States (US) (IMDb 2020). The Syrian civil war was in its sixth year, with Iran, the Russian Federation, Turkey and the US all involved, and with Islamic State losing its territorial footing in Syria and Iraq. Watching the series in September 2019-with Prime Minister Boris Johnson recently elected on the platform of delivering Brexit and three years of Trump's openly racist policies-I found the symbolism of Carnival Row to be obvious. The meaning with which the symbolic level is concerned is the interpretive code, the concealed or secret meaning of the represented sequence of events. A striking feature of the series is that it seems to require very little interpretation because the correlations between the work (the series) and the world are evident to anyone with a basic knowledge of current affairs in the Global North. The clash of empires in Tirnanoc recalls the coalition forces' invasion of Iraq, the subsequent destabilization of the Middle East and the rise of Islamic State. There are clear parallels between the Republic of the Burgue and the Pact in the fiction and the US and Islamic State in reality. Similarly, the Burgue, itself, is clearly a fictionalized New York or London—or, perhaps, Berlin, which received the greatest influx of asylum seekers in Europe in 2015 (Wolff 2018). The flight of the Fae from Tirnanoc to the Burgue evokes the flight of the hundreds of thousands of Syrians to European cities during the Syrian civil war and the passing of emergency legislation against the Fae represents the rise of right-wing populism. This symbolic correspondence is established quickly in the season, which initially appears to be didactic: much of the ambiguity and subtlety associated with the aural-visual work of art (Carnival Row) is sacrificed for the sake of conveying a simple and straightforward message.

As one might expect given the sophistication of the plot of Carnival Row, however, the series' symbolic meaning is also similarly complex, focused on speciesism (noted above) and its political exploitation. As explained in the previous part, the speciesist citizens of the Burgue believe they are morally superior to the Fae because they are human and the Fae belong to a separate and supposedly subhuman species. Many of these speciesists refer to the Fae using the derisive term, "Critch," and pursue some combination of making their lives as miserable as possible, proposing anti-immigration legislation, and using all available means to keep them offshore. Speciesism in Carnival Row is, in fact, symbolic of racism in our world and the series provides a rich and nuanced exploration of racism by means of its representation of speciesism. The standing in of "species" for "race" is not immediately obvious, not just because actors of different ethnicities are used to play both human and Fae characters, but because the symbolic meaning of the process of othering and the social construction of "species" upon which it is based signify racism and "race" in reality. Othering begins with the creation of a Manichaean binary opposition that follows the logic of the excluded middle, i.e., it admits of no exceptions (Fanon 1952). The positive pole and superior category is "human"- the species of homo sapiens sapiens - and its negation is the inferior category of Critch, which includes a wide variety of species-from tiny kobolds to giant centaurs - that share the negative characteristic of being "not human." There are no exceptions to the human or Critch rule. Philo, who is Breakspear's missing child, is a "half-blood," but he appears human because his wings were surgically removed as a baby. In sociological terminology, he can "pass" for human in the same way that many "non-Whites" can "pass for White" and, indeed, passing as human is a crime in the Burgue 
(Piper 1992: 13). When first his human lover and then his police colleagues become aware of this, Philo's ontological and moral status changes from the positive pole to the negative, rather than occupying any in-between status. Similarly, Philo's former comrade in arms, Darius (played by Ariyon Bakare), becomes Critch when he is infected with lycanthropy and mutates into a Marrock (werewolf). Both Philo and Darius are hybrids unrecognized in the speciesist binary opposition.

The othering is based on phenotypic traits, but they are not a necessary condition for the social construction of Critch. All of the species of Fae seen in the season are visibly different from humans. The main Fae characters are either faeries or fauns-the former distinguished by their wings and the latter by their horns and hooves. When it becomes known that Philo had a Faerie mother, however, he is ejected from the category of "human" and placed in that of "Critch" in spite of being identical to human beings in physical appearance. This is also true of Darius, whose physical appearance changes only on the nights when the moon is full. Like "race," in reality, the social construction of species in Carnival Row begins with phenotypic traits and is often focused on them, but ignores them as soon as there is any suggestion of the possibility of exception or hybridity. The slaves of the British West Indies were differentiated into "Negro" (Black), "mulatto" (one-half Black), "quadroon" (one quarter Black), "mustee" (one-eighth Black) and "mustefino" (one-sixteenth Black), but their legal, moral and social status was simply "non-White" (Woodson 1935: 43-44). "Racial" otherness and difference underpinned slavery in the Thirteen Colonies, as exemplified by the Virginia Slave Act of 1682, in which "Indians and Negroes were henceforth lumped together in Virginia legislation, and white Virginians treated black, red and intermediate shades of brown as interchangeable" (Morgan 1975: 329). This differentiation does not undermine the binary opposition but reinforces it and, in so doing, extends racism beyond the confines of phenotypic difference.

Carnival Row also examines the relationship between racism and xenophobia. This is particularly relevant to the contemporary parallel with the UK. Some advocates of Brexit are white supremacists, believing in the innate superiority of the White "race" over others, but as the majority of the population of the European Union would be classified as "White" by white supremacists, the relationship between racism and Brexit is complex (Pitcher 2019). One way to understand the intersection of different prejudices is that unlike the negative pole of the binary opposition, the positive pole is subject to meaningful subdivision. With respect to Brexit, a white supremacist might differentiate between "White British" and "White Other" (White Europeans) and have no objection to the presence of White Europeans in the country, but believe that belonging to the EU places the UK under obligation to accept "non-White" asylum seekers (Patel and Connelly 2019). The intersectional character of prejudice is represented in Sophie's inaugural speech to parliament in Episode 5 of Carnival Row:

It is not only my father's memory I wish to honor, but my mother's too. Her desert blood was written on her face as surely as it is written on mine. Her forefathers fled the chaos of war in the Pharaonic Coast and came to these shores, where the color of their skin made them outcasts. But, like so many others, they overcame the prejudices of that time and found a place in this great city ... and that speaks well of the Burgue and its values. Today, the chaos of war in the lands of the Fae has brought a new wave of refugees to these shores and they too are seen as outcasts. It is right to ask if our suspicions of these newcomers will one day be seen as a benighted vestige of the past. It is right to ask if we can overcome the differences between us and the Fae that rear our children, plough our fields, work our factories. I stand before you 
with my answer. We cannot. The Fae are nothing like us. Our differences are more than skin deep . . . and our Chancellor has turned a blind eye for far too long, but I

will not.

This places Sophie's ethnic group in a similar position to that of the Irish in the US in the early nineteenth century-victims of colonial persecution in the UK and perpetrators of "racial" oppression in the US (Allen 1994). Sophie's references to "skin color" ("race") and "new wave of refugees" (species) are symbolic of "nationality" and "race," respectively, in reality.

\section{Existential}

The existential or ethical level is concerned with individual desire and the construction of subjectivity. Jonathan Webber (2018: 1-2) defines the canonical existentialism of Jean-Paul Sartre, Simone de Beauvoir and Frantz Fanon as "the ethical theory that we ought to treat the freedom at the core of human existence as intrinsically valuable and the foundation of all other values." For Webber (2018: 11), this is a freedom-based value: the "virtue of authenticity is this respect for the structure of human agency." Authenticity has a long and complex history in philosophy, but the conception upon which Webber draws is Sartre's (1943) contrast of the authentic recognition of one's free will with the bad faith that refuses to accept free will. de Beauvoir $(1944,1948)$ makes a meticulous case for authenticity as a categorical imperative-beginning with freedom as the structure of human agency, then establishing the subjective value of that structure, and finally arguing that the structure is objectively valuable. In Carnival Row, the existential level of meaning is concerned primarily with what Derek Hook (2004: 85) refers to as "psychopolitics"- "the explicit politicisation of the psychological" - understood as the way in which historical and social circumstances shape and limit the creation of authentic selfhood. Fanon (1952, 1961), who was a practicing psychiatrist, argued that the colonial situation was crucially pathological, on the basis of the constitutive relation between colonialism and alienation-a process in which the Black subject is dehumanized.

Alienation is the separation of the Black subject's identity from that of the human being by virtue of her "race"- a process of dehumanization that emerges from the juxtaposition of Black and White. In his medical doctoral dissertation, Fanon claimed that alienation could not be explained without recourse to social relations (Khalfa 2018). Black Skin, White Masks (1952), published the year after his successful defense of that dissertation, is a literary, psychological and phenomenological account of Black experience and antiBlack racism that provides his most comprehensive account of alienation. In colonial contexts, the colonized subject is continually fed with values that are foreign, hostile and hierarchical to her own values - to the extent that the subject's mind is taken over (or colonized). Popular culture and education conspire to the extent that cultural imposition results in crystallization: "Gradually, a way of thinking and seeing that is basically white, forms and crystallises in the young Antillean" (Fanon 1952: 126). Crystallization causes internalization, in which the negative colonial stereotypes become part of the Black person's own subjectivity, such that she comes to forge the instruments of her own oppression. This inferiority complex involves the colonized subject aspiring to a Whiteness which she can never achieve, by virtue of her phenotypic traits - an essence for which she is not responsible. The subject is thus alienated from both her own culture (in aspiring to Whiteness) and from humanity (in failing to achieve Whiteness). 
Fanon (1952: 95) describes "racial" discrimination as follows: "I am overdetermined from the outside. I am a slave not to the "idea" others have of me, but to my appearance." The colonial situation produced individual pathologies by means of alienation, which required treatment directed at both agency and structure: "As a psychoanalyst I must help my patient to 'conciousnessize' his unconscious, to no longer be tempted by a hallucinatory lactification [aspiration to whiteness], but also to act along the lines of a change in social structure" (Fanon 1952: 80 (emphasis in original)).

At the existential level of meaning, Carnival Row is concerned with the way in which the social construction of Fae shapes and limits the authentic selfhood of the two protagonists-Vignette and Philo. Vignette is a victim of alienation in much the way Fanon describes, being overdetermined by her phenotypic traits and forced either to take her place in Burgue society as a servant or to live outside of it in the service of organized crime. The alienation suffered by Philo is more complex and the focus of his construction of subjectivity is on his personal identity. He is a mixed species being who passes as human-a decision that was made for him at birth, when his faerie wings were amputated. He cannot identify as mixed species because no such social or legal category is available in the Burgue, which is structured on the human-Critch binary. Consequently, Philo is necessarily alienated, forced to identify as either human or Fae despite belonging to neither category. As human, he is alienated by the species hierarchy that accords him superiority over the Fae, positioning him as both superior and inferior to himself. As Fae, he is alienated by his phenotypic traits, which overdetermine him as human. Philo fought for the Burgue in the war of imperial conquest against the Pact and led an inauthentic existence in which he concealed and repressed his Fae identity until he fell in love with Vignette. They were separated at the end of the war and Philo's inauthenticity was consolidated when he joined the police, enforcing a set of laws that he contravenes every day by passing as human. When Vignette appears in the Burgue and rejects him, he makes a decision to transcend his Fae identity by confessing his heritage to Portia (his human lover, played by Maeve Dermody) and making a commitment to living the rest of his life as a human. This commitment ends in disaster when he suffers a double reversal of fortune in which his passing is reported to the police by Portia and he is suspected of committing the Darkasher's murders.

In the dramatic sequence of events with which the series concludes, Philo reverses this decision. Following the Acting Chancellor's declaration, all Fae are interned in Carnival Row. When Philo and Vignette arrive at the gates, he is denied access on the basis of his human phenotypic traits and from across the barrier, she begs him to stay away for his own safety. The final dialogue of the season is between Philo and the guard who blocked his way (Carnival Row 2019):

Ghetto Guard:

Philo:
I told you, mate, it's just Critch, move on. I am Critch.

[The ghetto guard sneers at Philo and pushes him into Carnival Row.]

By voluntarily interning himself, Philo transcends his humanity, making a commitment to live the rest of his life as Fae. The consequences of this commitment are likely to be explored in the second season, but the perspective that the first season provides suggests that he will once again suffer alienation (albeit of a different kind). The fundamental problem is the influence of the speciesist structure of Burgue society on Philo's agency. Philo's desire is to achieve authentic selfhood by means of the construction of his subjective identity, but—like Fanon's Black subject—he finds himself the victim of a double alienation. 
First, there is no middle ground between the positive and negative poles of the binary opposition, so the only way that Philo can identify with his human heritage is to hide his Fae heritage. Second, no differences or distinctions are recognized within the negative pole of the opposition, so Philo's identification with his Fae heritage commits him to living in an internment camp for the colonized, where his phenotypic traits overdetermine him as a colonizer. His situation as a mixed-species character in the fictional world is a sophisticated development of Fanon's conception of alienation that provides alternative and complementary evidence for the injustice and irrationality of real societies in which "race" shapes and limits individual desire.

\section{Anthropic}

The anthropic or political level is concerned with collective ideology-the narrative of human achievement in which the construction of subjectivity is embedded. In Carnival Row, the anthropic level of meaning is primarily that which Norbert Elias (1986: 46; see also Elias 1988) referred to as a "decivilizing process"- the reversal of the historical trend toward increased empathy at the individual level and decreased violence at the collective level. The "decivilizing process" represented in the series is a consequence of the combination of two types of political violence, which Vincenzo Ruggiero (2020) calls "systemic violence" and "murderous martyrdom." "Systemic violence" is structural and institutional harm that "prevents its victims from satisfying their basic needs, and is an avoidable impairment of the fundamental means necessary for human existence" (Ruggiero 2020: 11). "Murderous martyrdom" is the corruption of an originally peaceful ideal to "connect the heroism of self-sacrifice with the deaths of others" (Ruggiero 2020: 171). Both of these conceptions of violence are explored in the character of Quill (played by Scott Reid), Jonah's faun valet. Quill is introduced in Episode 2, when he is searching The Tetterby Hotel (a Fae brothel in Carnival Row) for his master, Jonah (who has been kidnapped pursuant to Piety's orders). When he fails to find Jonah, he reports the disappearance to Breakspear's faun butler, Crick (played by an uncredited actor). Breakspear, who has thus far been represented as politically moderate and conscious of the moral status of the Fae, blames Quill for failing to prevent the abduction, verbally abuses him with speciesist slurs, and immediately dismisses him from service. What is particularly significant in this brief scene, foreshadowing what follows, is that the speciesism comes from a liberal politician, emerging under the stress of the situation, but suggesting that suspicion of the other is prevalent amongst all people (and, indeed, the Fae themselves).

Quill does not reappear onscreen until the beginning of Episode 5, when he is rummaging through a dustbin for food. He finds a soup kitchen run by a faun religious leader, Cabal (played by Theo Barklem-Biggs). Cabal feeds him and provides him with a copy of the Cyphers, a faun religious text, and he expresses an interest in learning more. Thus begins Quill's "radicalization," understood as a process in which he recognizes his personal suffering (unfair dismissal) as part of the broader oppression of a victimized community (fauns), identifies with that community (by joining the cult), and is motivated to take political action (Ruggiero 2020). Initially, this takes the form of peaceful protest, with Quill part of a public procession of approximately a dozen faun flagellants led by Cabal in Episode 6. When one of the flagellants is thrown to the ground and whipped by a speciesist human, Quill moves to help, but Cabal holds him back, stating: "Watch and learn. This . . . is the truth. They will never accept us. They will never understand us. We can make no peace with the ignorant" (Carnival 
Row 2019). Cabal is keen to exploit Quill's former position in the Breakspear household and the incident marks the escalation of his radicalization to "murderous martyrdom." The following episode finds Quill, Cabal and other sectarians in a faun temple where the violent human is being held prisoner. Cabal encourages Quill to kill the prisoner, suggesting that the Hidden one (the faun god) will reveal his plans to Quill if he proves his religious commitment. Quill cracks the man's skull with a stone tablet and Episode 8 opens with Quill murdering Crick. Using the butler's uniform, he infiltrates Balefire Hall, brings Breakspear a cup of tea, and then stabs him multiple times in a suicidal assassination attempt. Quill is, however, wrestled to the ground by guards and he is last mentioned as the victim of yet another kind of "systemic violence"-the enhanced interrogation the Burgue reserves for enemies of the state.

In making a murderous martyr of Quill, Cabal provides Sophie with precisely the opportunity for which she has been waiting. Quill's failure is twofold, achieving neither martyrdom nor murder as Breakspear survives the attack. When Piety visits him in his sickbed, he discloses his knowledge of her attempts to find and kill Philo in order to secure Jonah's legacy, telling her that Philo is no threat to Jonah because of his status as a half-blood. When he refuses to disclose Philo's whereabouts, Piety smothers him to death. In keeping with the custom of the Burgue, Jonah is appointed Acting Chancellor. He calls a cabinet meeting, declares a state of emergency under which all Fae in the Burgue are to be interned in Carnival Row, and addresses parliament:

We are a city under siege, from threats the likes of which my father could not have fathomed, threats from without and within. We stand at the precipice of a great and secret war. It is not a war we asked for, but by God it is a war we will win! Even now, measures are being taken to protect the people of this great city. We will prevail. We will steel ourselves against those who plot our destruction. We will meet their eyes and not blink. We will not compromise, we will not negotiate. We will hunt them to the very edge of the world.

Jonah then asks the Leader of the Opposition-Sophie-if she will cross the floor and unite with him; she agrees - to the bloodthirsty cheers of the assembly. The final twenty seconds of the season consists of two aerial shots of Carnival Row, with a voiceover of Sophie's response to Jonah: "Thank you, Chancellor. A new day is dawning. A change is coming to this city. Together, we have crossed a line in the sand and we can never go back."

Quill's radicalization and "murderous martyrdom" have been met with what Ruggiero (2020: 117) refers to as the "radicalization of democracy"- - a response to a threat to hegemony in which "the militarization of internal conflict and the transformation of domestic public spaces into war zones are accompanied by a parallel process occurring at the international level." This escalating radicalization is an example of the decivilizing process in action. Decivilization takes place on two interrelated levels.

At the individual level, there is a decrease in empathy, which is exemplified by the combination of Quill (who loses his empathy for humanity) and Sophie (who succeeds in reducing the empathy of other humans for the Fae). At the collective level, there is an increase in violence- "murderous martyrdom" from the Fae and "systemic violence" from humanity. Unlike the civilizing process, which was a persistent change in Europe across several centuries, the decivilizing process is local in both space and time-a short-term reversal in a particular place that is insufficient to disrupt the international trend (Elias 1939, 1986). Quill's failed assassination attempt on Breakspear and the Burgue's radical response resonate with the attacks in the US in 2001, UK in 2005, and France in 2015, as 
well as with the respective government's responses in terms of counter-terrorism, military action or both. If Elias' brief speculation on the decivilizing process is accurate, then the escalation of violence between Western governments and Islamicist extremists should be short-lived in historical terms. With the conflict shortly to enter its third decade, however, this is questionable. In Carnival Row, Sophie is determined that the decivilizing process she has orchestrated will be dynastic in proportion, although her reach beyond her own lifespan is limited. In the final part, I explain the series' unique contribution to zemiology.

\section{Zemiology}

In 'Race', Culture and the Right to the City: Centres, Peripheries and Margins, Millington (2011: 3) begins by distinguishing the global metropolis from the provincial city, identifying the former in terms of "the centralisation of capital and the corporate economy" and suggesting, for example, that London has more in common with New York and Paris than it does with Manchester and Leeds. Using London, New York and Paris as his case studies, Millington identifies three stages in the development of the global metropolis: the agonopolis, the cosmopolis, and the revanchist metropolis. Agonopolis refers to the "multiracial" city of the 1970s and 1980s, in which the metropolitan center became a site of "racial" tension and contestation-particularly, but not exclusively, its inner cities. The cosmopolis is an ideal inspired by the globalization of the nineteen nineties and pursued in the following decade in which demographic diversity is not only recognized but valued. As such, the cosmopolis is "a metropolis that is now post- "race"" (Millington 2011: 108), where conviviality has replaced conflict and the right to the city-Henri Lefebvre's (1968) conception of the availability of the urban center-is determined by socioeconomic status rather than "race." The revanchist metropolis, which is my term rather than Millington's, describes the reality of the three metropolises in the twenty-first century, in which the urban center has been reclaimed by the wealthy, White population and the poor, "multiracial" population has been expelled to the "racialised 'outer-inner city" (Millington 2011: 150). Millington explores the revanchist reality of the cosmopolitan ideal by means of the concepts of melancholia (London), postcolonialism (Paris) and marginality (New York).

With Millington's (2011) ideas in mind, we can consider the Burgue as a global metropolis-a large city-state with access to the ocean that has become a hub for international capital and has imperial ambitions, most recently thwarted by the Pact in Tirnanoc. It is an agonopolis, with Carnival Row itself an inner city-a site of tension and contestation between species (where species is symbolic of "race," as discussed above). The Burgue is, like London, Paris and New York in the early 1990s, a metropolis in transition-and in Carnival Row, the transition is driven by the loss of the war in Tirnanoc. The Burgue's military withdrew from Tirnanoc seven years before the series starts and the opening of the first episode makes it clear that the Pact's colonial rule of the Fae has been characterized by a combination of slavery and genocide. The desire of large numbers of Fae to leave their homeland has been facilitated and exploited by the merchants of the Burgue and other human countries, who offer escape in exchange for indentured service. In consequence, the Burgue has been provided with a cheap source of labor and developed a "multiracial" identity. While the financial, political and social elite are pleased about the former, they are ambivalent about the latter and the "Fae question" is the subject of heated debate in parliament. The Burgue is thus an agonopolis in crisis-at the tipping point of becoming either a cosmopolis or a revanchist metropolis. Although the first season ends with a decisive and 
explicit movement toward the latter, there are several indications that revanchism was not inevitable and that in the absence of Piety and Sophie's respective machinations, the Burgue may have at least aspired to the cosmopolitan ideal. The possibility of a less harmful metropolis is represented in the characters of Aisling (played by Erika Starkova), Philo's faerie mother, and Agreus (played by David Gyasi), a faun who belongs to the financial elite. Both characters have been successful in rising above the socioeconomic status reserved for the Fae and been, to some extent, accepted into human society-Aisling in virtue of her talent as a singer and Agreus in virtue of his wealth. While Sophie and Jonah pursue revanchism at the anthropic level, the season sees the destruction of both of these hopes for a more just city at the existential level: Aisling is killed by the Darkasher as part of Piety's plan to secure Jonah's legacy and Agreus flees the Burgue when his interspecies relationship provokes violence from the social elite.

In general, the zemiological project aims to produce theoretical and methodological tools to identify preventable harm for the purpose of reducing that harm (Atkinson and Millington 2019; Hillyard and Tombs 2004; Pemberton 2016). The chain of causation from zemiology to harm reduction proceeds as follows: zemiological inquiry identifies the cause or causes of a particular preventable harm; the findings of the research are translated into a policy for one or more government or private agencies with the aim of reducing or removing the causal factor or factors; and the policy is put into practice resulting in the reduction in certain types of harm or of the commission of various harms by certain categories of perpetrator, which may include the state, itself, its agencies, or corporations (Barton et al. 2018; Pemberton 2016; Presser 2013). The key factor that links zemiological research to harm reduction is the explanation of the cause of the harm. Consequently, the zemiological value of Jameson's (2019) fourfold model of allegory is the value of that model in explaining the causes of harm. If one rejects the recent view of fiction as having little or no relation to reality, as I recommended above, then there can be little doubt that Carnival Row provides convincing explanations of causes of the urban harms of racism, alienation and decivilization at its symbolic, existential and anthropic levels of meaning. These explanations are, however, no more than could be constructed by applying the theories of Allen (1994), Fanon $(1952,1961)$ and Ruggiero (2020) to real global metropolises, and this type of urban analysis would likely be both more valid and more reliable than any allegorical analysis, on the basis of the tolerance of inventiveness, imaginativeness and fabrication in the practice of fiction. In other words, in order for zemiologists to take Jameson's (2019) model of fourfold allegory seriously, it must be able to make a contribution to the etiology of harm because of the fictionality of the allegories interpreted rather than in spite of the fictionality of those allegories (McGregor 2018; Millington and Rizov 2019). This is precisely what Jameson's model achieves with Carnival Row, exploring the zemiological value of the allegory as a fictional narrative event.

As described above, Jameson (2019) contends that allegorical narratives are both fourfold and thick: they operate on four levels of meaning among which there is a multiplicity of intersections. These intersections create meaning that is in excess of the representational capacity of the narrative and activate an event in which the reader or viewer grasps this extra-representational meaning. For Jameson (2019), the narrative event of allegory is revelatory both aesthetically and politically, disclosing the complexity of its architecture of multiple meanings as well as the otherwise imperceptible connections among the dimensions of late modern life. The crucial point about the political revelation-the connections among the dimensions of late modern life-is that they are otherwise imperceptible. I take this to mean that allegory is the most valid and the most reliable way of explaining at least 
some of these connections rather than that the connections cannot be explained in any other way.

In Carnival Row, the dimensions are racism, alienation and decivilization, and their zemiological relevance is the causal contribution of their connections to the revanchism characteristic of the global metropolis in the twenty-first century. The series explores the Burgue, which is representative of the agonopolis, by the combination of its postcolonial epic, murder mystery and paranormal romance plotlines at the literal level of meaning. At the symbolic level, the speciesism suffered by Philo, Quill, Vignette and others is representative of the harm of racism, providing a rich and nuanced analysis of the social construction of "race," the relevance of phenotypic traits and the relationship between racism and xenophobia. At the existential level, the moral dilemma Philo faces because of his interspecies heritage is representative of the harm of alienation and is a sophisticated development of Fanon's (1952) initial conception of this "race"-based harm. At the anthropic level, Carnival Row illuminates the harm of decivilization in terms of the relationship between Ruggiero's (2020) systemic violence and murderous martyrdom, exemplified in the contrast of Sophie with Quill. The aural-visual experience of watching the series is not just a physical, conceptual, emotional and evaluative experience of these four representative levels, but an event in which they are experienced simultaneously and interactively (Jameson 2019; McGregor 2016). The event of Carnival Row, then, is one in which the relationships among the harms of racism, alienation and decivilization are disclosed by the combination of character, setting and action. Sophie is particularly significant in this regard and her direct and indirect impact on the lives of Piety, Philo and Quill reveals connections among racism, alienation and decivilization that would be difficult to communicate by means of a documentary or discursive text.

The illumination of the connections among these three different harms is both interesting and useful from a zemiological perspective, but the real zemiological value of Carnival Row is the narrative event's allegorical staging of the harmful regression from agonopolis to revanchist metropolis. The series opens with an agonopolis in crisis, presents the cosmopolitan and revanchist options for that agonopolis, and explains how racism, alienation and decivilization combine to secure a revanchist future. The season ends with Sophie's assumption of power by means of a speciesist platform, Piety dead because of her dynastic obsession, Vignette and Philo interned in the Fae ghetto, and Quill under enhanced interrogation. Carnival Row's contribution to zemiology is its explanation of revanchism as a complex combination of racism, alienation and decivilization and its exploration of cause and effect in both the personal and public spheres. It would be an exaggeration to claim that the contribution of racism, alienation and decivilization to the revanchism of London, Paris and New York in the twenty-first century is imperceptible. Millington's (2011) study is of "racial" injustice in the global metropolis and had he envisaged a more significant role for alienation and decivilization in the revanchist regression, he could, no doubt, have articulated these in a discursive manner. Jameson's point, as I take it, is that the use of allegory provides the most efficient means to articulate the causal relationships staged by the narrative. As such, Carnival Row functions as an extension of Millington's thesis, presenting alienation and decivilization as an alternative to the melancholic, postcolonial and marginal routes to revanchism. The zemiological value of allegory is not, of course, restricted to Carnival Row's explanation of the causes of urban revanchism; its potential can be realized by many allegories that meet Jameson's criteria of fourfoldness and thickness. Recent examples that have obvious zemiological relevance include J.M. Coetzee's Waiting for the Barbarians (1980), Octavia Butler's Parable of the Sower (1993), China Miéville's The City \& the City (2009), and Margaret Atwood's The Testaments (2019). Jameson's model 
of fourfold allegory offers zemiologists a methodological tool for exploring the causes of harm in late modernity and that tool is none the less useful for its association with the practice of fiction as I have demonstrated with Carnival Row and urban revanchism.

Open Access This article is licensed under a Creative Commons Attribution 4.0 International License, which permits use, sharing, adaptation, distribution and reproduction in any medium or format, as long as you give appropriate credit to the original author(s) and the source, provide a link to the Creative Commons licence, and indicate if changes were made. The images or other third party material in this article are included in the article's Creative Commons licence, unless indicated otherwise in a credit line to the material. If material is not included in the article's Creative Commons licence and your intended use is not permitted by statutory regulation or exceeds the permitted use, you will need to obtain permission directly from the copyright holder. To view a copy of this licence, visit http://creativecommons.org/licenses/by/4.0/.

\section{References}

Ackroyd, P. (2000/2001). London: The Biography. London: Vintage.

Alighieri, D. (1472). La Comedia di Dante Alleghieri. Foligno: Johann Numeister and Evangelista Angelini da Trevi.

Allen, T.W. (1994). The Invention of the White Race Volume I: Racial Oppression and Social Control. London: Verso Books.

AlSayyad, N. (2006). Cinematic Urbanism: A History of the Modern from Reel to Real. New York: Routledge.

Atkinson, R. \& Millington, G. (2019). Urban Criminology: The City, Disorder, Harm and Social Control. Abingdon, Oxon, UK: Routledge.

Atwood, M. (2019). The Testaments. Toronto: McClelland \& Stewart.

Barton, A., Davis, H. \& White, H. (2018). Agnotology and the Criminological Imagination. In A. Barton \& H. Davis (Eds.), Ignorance, Power and Harm: Agnotology and The Criminological Imagination (pp. 13-35). London: Palgrave MacMillan.

Beirne, P. (2018). Murdering Animals: Writings on Theriocide, Homicide and Nonspeciesist Criminology. London: Palgrave Macmillan.

Beauvoir, S. de (1944). Pyrrhus and Cineas. In S. de Beauvoir, Philosophical Writings (pp. 77-149). Trans. M. Timmermann. Champaign, IL: University of Illinois Press.

Beauvoir, S. de (1948/1976). The Ethics of Ambiguity. Trans. B. Frechtman. New York: Citadel Press.

Boukli, A. \& Kotzé, J. (2018). Introduction. In A. Boukli \& J. Kotzé (Eds.), Zemiology: Reconnecting Crime and Social Harm (pp. 1-8). London: Palgrave Macmillan.

Brisman, A. (2017). On Narrative and Green Cultural Criminology. International Journal for Crime, Justice and Social Democracy, 6(2), 64-77.

Brisman, A. (2019). The Fable of The Three Little Pigs: Climate Change and Green Cultural Criminology. International Journal for Crime, Justice and Social Democracy, 8(1), 46-69.

Brown, M. (2004). Crime Fiction and Criminology. Criminal Justice Review, 29(1), 206-20.

Butler, O.E. (1993). The Parable of the Sower. New York: Four Walls Eight Windows.

Carnival Row. (2019). Originally released August 30. US: Prime Video.

Cavender, J. \& Jurik, N.C. (2012). Justice Provocateur: Jane Tennison and Policing in Prime Suspect. Champaign, IL: University of Illinois Press.

Coetzee, J.M. (1980). Waiting for the Barbarians. London: Secker \& Warburg.

Elias, N. (1939). The Civilizing Process: Sociogenetic and Psychogenetic Investigations. Trans. E. Jephcott. Malden, MA: Blackwell Publishing.

Elias, N. (1986). Introduction. In N. Elias \& E. Dunning (Eds.), Quest for Excitement: Sport and Leisure in the Civilizing Process (pp. 19-62). Oxford: Basil Blackwell.

Elias, N. (1988). Wir sind die späten Barbaren. Der Spiegel, 21(42)[May 23], 183-90.

Fanon, F. (1952). Black Skin, White Masks. Trans. R. Philcox. New York: Grove Press.

Fanon, F. (1961). The Wretched of the Earth. Trans. R. Philcox. New York: Grove Press.

Ferrell, J., Hayward, K. \& Young, J. (2015). Cultural Criminology: An Invitation. $2^{\text {nd }}$ ed. London: SAGE Publications. 
Frauley, J. (2010). Criminology, Deviance, and the Silver Screen: The Fictional Reality and the Criminological Imagination. New York: Palgrave Macmillan.

Goethe, J.W. von (1832). Faust. Der Tragödie zweiter Teil in fünf Akten. Stuttgart: Cotta.

Hayward, K. \& Hall, S. (2021). Through Scandinavia, Darkly: A Criminological Critique of Nordic Noir. The British Journal of Criminology, 61(1), 1-21. https://doi.org/10.1093/bjc/azaa044.

Highmore, B. (2005). Cityscapes: Cultural Readings in the Material and Symbolic City. London: Palgrave Macmillan.

Hillyard, P. \& Tombs, S. (2004). Beyond criminology? In P. Hillyard, C. Pantazis, S. Tombs, \& D. Gordon (Eds.), Beyond Criminology: Taking Harm Seriously (pp. 10-29). London: Pluto Press.

Hook, D. (2004). Frantz Fanon, Steve Biko, 'psychopolitcs' and critical psychology. In D. Hook (Ed.), Critical Psychology (pp. 84-114). Cape Town: Juta Academic Publishing.

Internet Movie Database (IMDb) (2020). Carnival Row. Filming \& Production. Retrieved on January 26, 2021, from https://www.imdb.com/title/tt0489974/locations?ref_=tt_q1_dt_5.

Jameson, F. (2015). The Ancients and the Postmoderns: On the Historicity of Forms. London: Verso.

Jameson, F. (2019). Allegory and Ideology. London: Verso.

Khalfa, J. (2018). Fanon, revolutionary psychiatrist. In F. Fanon, Alienation and Freedom (pp. 167-202). Trans. S. Corcoran. London: Bloomsbury.

Lefebvre, H. (1968). The Right to the City. In H. Lefebvre, Writings on Cities (pp. 61-181). Trans. E. Kofman \& E. Lebas. Oxford: Blackwell Publishers.

McGregor, R. (2016). The Value of Literature. London: Rowman \& Littlefield International.

McGregor, R. (2018). Narrative Justice (2018). London: Rowman \& Littlefield International.

McGregor, R. (2020). Criminological Fiction: What is it good for? Journal of Theoretical \& Philosophical Criminology, 12(January), 18-36.

Marx, K. (1859). A Contribution to the Critique of Political Economy. Trans. S.W. Ryazanskaya. Moscow: Progress Publishers.

Miéville, C. (2009). The City \& the City. London: Macmillan.

Millington, G. (2011). 'Race', Culture and the Right to the City: Centres, Peripheries, Margins. London: Palgrave Macmillan.

Millington, G. (2016). Urbanization and the Migrant in British Cinema: Spectres of the City. London: Palgrave Macmillan.

Millington, G. \& Rizov, V. (2019). 'What makes city life meaningful is the things we hide': A dialogue on existential urban space between Marshall Berman and Orhan Pamuk. City, 23(6), 697-713. https://doi. org/10.1080/13604813.2020.1718961.

Mitchell, D. (2004). Cloud Atlas. London: Sceptre.

Morgan, E.S. (1975). American Slavery, American Freedom: The Ordeal of Colonial Virginia. New York: W.W. Norton \& Company.

Page, J. \& Goodman, P. (2020). Creative disruption: Edward Bunker, carceral habitus, and the criminological value of fiction. Theoretical Criminology, 24(2), 222-240.

Patel, T. \& Connelly, L. (2019). 'Post-race' racisms in the narratives of 'Brexit' voters. The Sociological Review, 67(5), 968-984.

Pemberton, S. (2016). Harmful Societies: Understanding Social Harm. Bristol, UK: Policy Press.

Penz, F \& Lu, A. (2011). Introduction: What is Urban Cinematics? In F. Penz \& A. Lu (Eds.), Urban Cinematics: Understanding Urban Phenomena Through the Moving Image (pp. 7-19). Chicago: Intellect.

Piper, A. (1992). Passing for White, Passing for Black. Transition, 58, 4-32.

Pitcher, B. (2019). Racism and Brexit: notes towards an antiracist populism. Ethnic and Racial Studies, 42(14), 2490-2509.

Presser, L. (2013). Why We Harm. New Brunswick, NJ: Rutgers University Press.

Rafter, N. (2006). Shots in the Mirror: Crime Films and Society. $2^{\text {nd }}$ ed. New York: Oxford University Press.

Rafter, N. (2007). Crime, film and criminology: Recent sex-crime movies. Theoretical Criminology, 11(3), 403-20.

Raymen, T. (2018). Living in the end times through popular culture: An ultra-realist analysis of The Walking Dead as popular criminology. Crime Media Culture: An International Journal, 14(3), 429-47.

Ruggiero, V. (2003). Crime in Literature: Sociology of Deviance and Fiction. London: Verso.

Ruggiero, V. (2020). Visions of Political Violence. Abingdon, Oxon, UK: Routledge.

Sartre, J.P. (1943). Being and Nothingness: An Essay on Phenomenological Ontology. Trans. S. Richmond. Abingdon, Oxon, UK: Routledge.

Shakespeare, W. (1603). The Tragicall Historie of Hamlet Prince of Denmarke. London: 1lers Nicholas Ling \& John Trundell.

Singer, P. (1993). Practical Ethics. Cambridge, UK: Cambridge University Press. 
Sollund, R.A. (2019). The Crimes of Wildlife Trafficking: Issues of Justice, Legality and Morality. Abingdon, Oxon, UK: Routledge.

Spenser, E. (1590). The Faerie Queene. London: William Ponsonby.

Vidmar Jovanović, I. (2019). Cognitive and Ethical Values and Dimensions of Narrative Art. In I. Vidmar Jovanović (Ed.), Narrative Art, Knowledge and Ethics (pp. 17-85). Rijeka: University of Rijeka.

Wakeman, S. (2018). The 'one who knocks' and the 'one who waits': Gendered violence in Breaking Bad. Crime Media Culture: An International Journal, 14(2), 213-228.

Webber, J. (2018). Rethinking Existentialism. Oxford: Oxford University Press.

Williams, B. (1985). Ethics and the Limits of Philosophy. London: Fontana Press.

Williams, R. (1958/2017). Culture and Society 1780-1950. London: Vintage.

Wolff, J.S. (2018). Hamburg, Germany: A Preliminary Case Study of Refugees in Towns. Feinstein International Center, Friedman School of Nutrition Science and Policy, Tufts University. April. Retrieved on January 26, 2021, from https://static1.squarespace.com/static/599720dc59cc68c3683049bc/t/5ce7e e9941920283938b9039/1558703771945/RIT+Report+Hamburg+Germany.pdf.

Wood, M.A. (2019). Algorithmic tyranny: Psycho-Pass, science fiction and the criminological imagination. Crime, Theory, Culture: An International Journal, 15(2), 323-339.

Woodson, C.G. (1935). The Story of the Negro Retold. Washington, DC: The Associated Publishers Inc.

Publisher's Note Springer Nature remains neutral with regard to jurisdictional claims in published maps and institutional affiliations. 